\title{
Combined bioelectrochemical and sulfur autotrophic denitrification for drinking water treatment
}

\author{
Haiyan Wang, Jiuhui Qu* \\ State Key Laboratory of Environmental Aquatic Chemistry, Research Center for Eco-Environmental Sciences, \\ Chinese Academy of Sciences, P.O. Box 2871, Beijing 100085, China
}

Received 3 September 2002; received in revised form 14 April 2003; accepted 17 April 2003

\begin{abstract}
A combined bioelectrochemical and sulfur autotrophic denitrification process for drinking water treatment was put forward and investigated extensively in this paper. In this new process, the bioelectrochemical denitrification was carried out in the upper part of the reactor while sulfur denitrification in the lower part. The $\mathrm{H}^{+}$produced in Sulfur Part could be consumed by hydrogen denitrification in Bioelectrochemical Part. Therefore, the limestone for $\mathrm{pH}$ adjustment in Sulfur Part was not necessary in this combined process, which avoided the problem of hardness increase. The sulfate accumulation in this combined reactor was less than that of the sulfur limestone autotrophic denitrification system. The effluent from two parts was kept neutral at optimum operation conditions. When the influent nitrate was $30 \mathrm{mg}-\mathrm{N} / \mathrm{L}$, the reactor could be operated efficiently at the hydraulic retention time ranged from 1.9 to $5 \mathrm{~h}$ (corresponding minimum current was $16-3 \mathrm{~mA}$ ), i.e. the effluent $\mathrm{NO}_{3}^{-}-\mathrm{N}$ removal ranged from $90 \%$ to $100 \%$ without nitrite accumulation and the effluent sulfate concentration was lower than $170 \mathrm{mg} / \mathrm{L}$. The maximum volume-loading rate of the reactor was $0.381 \mathrm{~kg}$ $\mathrm{NO}_{3}^{-}-\mathrm{N} /\left(\mathrm{m}^{3} \mathrm{~d}\right)$. The biomass and scanning electron microscope micrographs of Sulfur Part were also analyzed.
\end{abstract}

(C) 2003 Elsevier Science Ltd. All rights reserved.

Keywords: Combined bioelectrochemical and sulfur process; Hydrogen; Autotrophic denitrification; Drinking water

\section{Introduction}

Nitrate contamination of groundwater is becoming more and more serious in many countries [1]. In China, the nitrate contamination of drinking water increases rapidly, and the nitrate concentration in some drinking water source is higher than $30 \mathrm{mg}-\mathrm{N} / \mathrm{L}$ [2]. It is reported by World Health Organization that the nitrate concentration in drinking water should be lower than $10 \mathrm{mg}-\mathrm{N} /$ L [3]. Nitrate can cause methemoglobinemia when ingested by infants [4-6], and they can even cause carcinoma, malformation and mutation when transformed into nitrosoamines [7].

Biological denitrification process, which comprises autotrophic denitrification and heterotrophic denitrifica-

\footnotetext{
*Corresponding author. Tel.: + 86-10-6284-9151; fax: +8610-6284-9160.

E-mail address: jhqu@mail.rcees.ac.cn (J. Qu).
}

tion, is considered an efficient technology in the treatment of nitrate-contaminated water. Heterotrophic denitrification is very efficient in nitrate removal if adequate amounts of organic carbon are available. However, in drinking water treatment, insufficient organic carbon may limit the application of heterotrophic denitrifcation unless external organic carbon sources are supplied [8]. Autotrophic denitrification has been booming recently due to two major advantages compared with heterotrophic denitrification: (1) no external carbon is needed, which reduces the cost and risk of operation and (2) less sludge is produced, which minimize the bacteria in the effluent [9]. Both of hydrogen gas and elemental sulfur can be used as ideal electron donor for autotrophic denitrification because they are completely harmless to human health, and no further steps are needed to remove either excess substrate or its derivatives [10,11].

Hydrogen gas is a kind of clean electron donor for autotrophic denitrification, however, its transportation 
and generation is dangerous and expensive. In a new electrode-biofilm reactor $[12,13]$, denitrifying microorganisms immobilized on the cathode will utilize $\mathrm{H}_{2}$, which is produced by the electrolysis of water, to convert nitrate into $\mathrm{N}_{2}$. Thus, the problems of hydrogen gas transportation and generation could be avoided. The feasibility of nitrate contaminated water treatment by electrode-biofilm reactor has been investigated experimentally and theoretically, and the nitrate removal efficiency could reach $100 \%$. A study on the use of bipolar-particles-electrodes-biofilm in potable water denitrification showed that the electric utilization efficiency could get to $200 \%$ [2].

Sulfur limestone autotrophic denitrification (SLAD) systems have been studied widely in Europe and USA $[8,9,14,15]$, and their high denitrification efficiency can be compared with that of the heterotrophic denitrification in the nitrate-contaminated water treatment. In such processes, elemental sulfur is used as electron donor while limestone is used to adjust the $\mathrm{pH}$ and $7.54 \mathrm{mg} / \mathrm{L}$ sulfate will be produced stoichiometrically when $1 \mathrm{mg}-\mathrm{N} / \mathrm{L}$ nitrate is removed. There will be hardness increase in treated water because of $\mathrm{Ca}^{2+}$ produced by the limestone for $\mathrm{pH}$ adjustment.

The electron donor and $\mathrm{pH}$ values are the key influencing factors for autotrophic denitrification process. In order to take full advantage of bioelectrochemical hydrogen denitrification and elemental sulfur denitrification, a new combined bioelectrochemical and sulfur autotrophic denitrification (CBSAD) process was brought forward and studied. The advantages of the two processes were integrated in this CBSAD process. On one hand, the $\mathrm{H}^{+}$produced by sulfur denitrification was helpful to the bioelectrochemical hydrogen denitrification at the cathode, thus the hydrogen denitrification could be carried out easily. On the other hand, because the $\mathrm{H}^{+}$produced in sulfur denitrification was consumed by the bioelectrochemical hydrogen denitrification, the $\mathrm{pH}$ adjustment limestone was not necessary and the effluent hardness increase could be avoided. Furthermore, the $\mathrm{CO}_{2}$ produced on anode can serve as the supplement of inorganic carbon (IC) source and $\mathrm{pH}$ buffer to the whole denitrification. The effluent sulfate concentration could be controlled through the hydraulic retention time (HRT) and current adjustment. The feasibility of this CBSAD process was verified and its optimum operation conditions were presented.

\section{Materials and methods}

\subsection{Experimental set-up}

As shown in Fig. 1, the reactor consisted of two parts, i.e., the bioelectrochemical hydrogen autotrophic denitrification part (hereinafter referred to as Bioelectro-

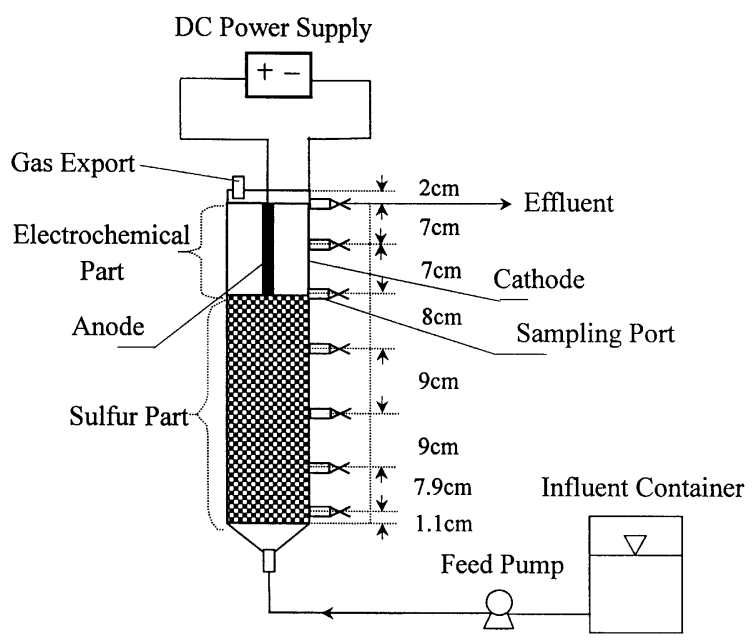

Fig. 1. The experimental set-up.

chemical Part) and the sulfur autotrophic denitrification part (hereinafter referred to as Sulfur Part). The effective volume of the reactor was $1.23 \mathrm{~L}$. Bioelectrochemical Part, which was in the upper part of the reactor, was made of stainless steel column with $7.28 \mathrm{~cm}$ diameter and $16 \mathrm{~cm}$ length, and its effective volume was $0.52 \mathrm{~L}$. The anode was carbon rod of $2.5 \mathrm{~cm}$ diameter and $14 \mathrm{~cm}$ length and the cathode was the cylindrical stainless steel wall with $321 \mathrm{~cm}^{2}$ surface area. The distance between the electrodes was $2.4 \mathrm{~cm}$. Sulfur Part was a cylindrical plexiglas in the lower part of the reactor with $7.28 \mathrm{~cm}$ diameter and $35 \mathrm{~cm}$ length. $746 \mathrm{~g}$ sulfur granules (Luoyang Sunrise Industrial Co., Ltd, Luoyang, China), which are of 3.0-4.0 mm diameter, were packed in Sulfur Part. The reactor was kept in the incubator at constant temperature of $30^{\circ} \mathrm{C}$. Silicon Rectifier (Model GCA12/ 14, Beijing Chunshu Rectifier Instruments Plant, Beijing, China) supplied direct current to the reactor.

\subsection{Experimental design}

The whole experiment included three stages: preinoculation stage, inoculation-acclimation stage and operation stage. The influent was mixed by tap water (Beijing No. 9 Water Plant) and other ingredients as listed in Table 1, and the IC in the tap water was $8 \mathrm{mg}-\mathrm{C} /$ L. All chemicals used in this experiment were of analytical grade (Beijing Agent Plant, Beijing, China).

The variation of the oxidation-reduction potential (ORP), $\mathrm{pH}, \mathrm{TOC}, \mathrm{NO}_{3}^{-}-\mathrm{N}$, and $\mathrm{NO}_{2}^{-}-\mathrm{N}$ in the CBSAD reactor were monitored at different $\mathrm{HRT}$ and current at pre-inoculation stage.

At inoculation-acclimation stage, the CBSAD reactor was inoculated with the effluent from a heterotrophic denitrification system. Under continuous-flow, biofilm was formed on the cathode and sulfur granule surface in 
Table 1

Influent ingredients and applied current at different stages

\begin{tabular}{|c|c|c|c|}
\hline \multirow[t]{2}{*}{ Ingredients } & \multicolumn{3}{|l|}{ Time } \\
\hline & Pre-inoculation stage (14d) & $\begin{array}{l}\text { Inoculation } \\
\text { acclimation stage } \\
(100 \mathrm{~d})\end{array}$ & Operation stage $(400 \mathrm{~d})$ \\
\hline $\mathrm{NaNO}_{3}(\mathrm{mg}-\mathrm{N} / \mathrm{L})$ & 30 (adding $20 \mathrm{mg}-\mathrm{N} / \mathrm{L} \mathrm{NaNO}_{2}$ ) & 30 & 30 \\
\hline Phosphate & $\begin{array}{l}7.7 \mathrm{ml}-\mathrm{Buffer} / \mathrm{L} \text { (Buffer:025 M } \\
\mathrm{Na}_{2} \mathrm{HPO}_{4} \cdot 12 \mathrm{H}_{2} \mathrm{O} \& 0.025 \mathrm{M} \\
\mathrm{KH}_{2} \mathrm{PO}_{4} \text { ) }\end{array}$ & $\begin{array}{l}7.7 \mathrm{ml}-\mathrm{Buffer} / \mathrm{L} \\
\text { (Buffer:025 M } \\
\mathrm{Na}_{2} \mathrm{HPO}_{4} \cdot 12 \mathrm{H}_{2} \mathrm{O} \& \\
\left.0.025 \mathrm{M} \mathrm{KH}_{2} \mathrm{PO}_{4}\right)\end{array}$ & $2 \mathrm{mg}-\mathrm{P} / \mathrm{L} \mathrm{KH}_{2} \mathrm{PO}_{4}$ \\
\hline \multirow{2}{*}{$\begin{array}{l}\mathrm{CH}_{3} \mathrm{OH}(\mathrm{mg}-\mathrm{C} / \mathrm{L}) \& \\
\text { according electric } \\
\text { current }(\mathrm{mA})\end{array}$} & 0\&:2-20 HRT $1.5 \mathrm{~h}(1 \mathrm{~d})$ & & \\
\hline & $\begin{array}{l}0 \&: 2-20 \text { HRT } 2 \text { h }(2 \mathrm{~d}) \\
0 \&: 2-20 \text { HRT } 4 \mathrm{~h}(2 \mathrm{~d}) \\
0 \&: 2-20 \text { HRT } 8 \mathrm{~h}(2 \mathrm{~d}) \\
0 \&: 2-20 \text { HRT } 10 \mathrm{~h}(2 \mathrm{~d}) \\
0 \&: 2-20 \text { HRT } 12 \mathrm{~h}(2 \mathrm{~d}) \\
0 \&: 2-20 \text { HRT } 14 \mathrm{~h}(3 \mathrm{~d})\end{array}$ & $\begin{array}{l}90 \& 0(30 d) \\
80 \& 2(14 d) \\
60 \& 4(14 d) \\
30 \& 6(14 d) \\
15 \& 8(14 d) \\
0 \& 10(14 d)\end{array}$ & $\begin{array}{l}\text { 0\&:2-20 HRT } 1.9 \mathrm{~h}(72 \mathrm{~d}) \\
0 \&: 2-20 \text { HRT } 2.5 \mathrm{~h}(72 \mathrm{~d}) \\
0 \&: 2-20 \text { HRT } 3.0 \mathrm{~h}(72 \mathrm{~d}) \\
0 \&: 2-20 \text { HRT } 4.0 \mathrm{~h}(72 \mathrm{~d}) \\
0 \&: 2-20 \text { HRT } 5.0 \mathrm{~h}(72 \mathrm{~d})\end{array}$ \\
\hline
\end{tabular}

about 1 month. The influent, in which the ratio of carbon to $\mathrm{NO}_{3}^{-}-\mathrm{N}$ was $3: 1$, was delivered to the reactor by a pump (Model EH-B310-220R4, Iwaki Co., Ltd., Tokyo, Japan). The $\mathrm{pH}$ was kept neutral by buffering solution of $\mathrm{K}_{2} \mathrm{HPO}_{4}$ and $\mathrm{KH}_{2} \mathrm{PO}_{4}$ with the ratio of $1: 1$. When the biofilm was formed on the cathode and sulfur granule surface, direct current was applied gradually from 2 to $10 \mathrm{~mA}$ to acclimatize the bacteria. Meanwhile, the ratio of carbon to nitrogen in the influent was decreased to zero gradually, and then the reactor was operated under complete autotrophic denitrification. When this CBSAD system was acclimated to complete autotrophic denitrification, the $\mathrm{pH}$ buffering system was removed and only $2 \mathrm{mg}-\mathrm{P} / \mathrm{L} \mathrm{K} \mathrm{K}_{2} \mathrm{HPO}_{4}$ was added to the influent as nutrition.

Optimum operation conditions were determined at the operation stage. The system was tested at HRT of $1.9,2.5,3.0,4.0,5.0$ and $6.0 \mathrm{~h}$. At each HRT, direct current of $2,4,6,8,10,12,14,16,18,20 \mathrm{~mA}$ were applied to the reactor sequentially. The quasi-steadystate experiment started at the highest HRT $(6 \mathrm{~h})$ and then run sequentially. Under different HRT and current, the system run and stabilized over 2 days. The system was not considered in quasi-steady-state condition until the sample data $\left(\mathrm{NO}_{3}^{-}, \mathrm{NO}_{2}^{-}, \mathrm{SO}_{4}^{2-}\right.$, biomass concentration and $\mathrm{pH}$ in the effluent) variation of three sequential retention times was less than $5 \%$. Under quasi-steadystate condition, the corresponding experiment or measurements were conducted. All the data in this paper were the average value of the three sequential samples within $5 \%$ variation.

\subsection{Analytical methods}

The $\mathrm{NO}_{3}^{-}-\mathrm{N}, \mathrm{NO}_{2}^{-}-\mathrm{N}, \mathrm{SO}_{4}^{2-}, \mathrm{pH}$, biomass, total organic carbon (TOC) and total chemical oxygen demand (TCOD) of the influent, Sulfur Part effluent and Bioelectrochemical Part effluent were measured at each quasi-steady-state condition. Samples were filtered through $0.45 \mu \mathrm{m}$ membrane for $\mathrm{NO}_{3}^{-}-\mathrm{N}, \mathrm{NO}_{2}^{-}-\mathrm{N}, \mathrm{SO}_{4}^{2-}$ and TOC analysis. The $\mathrm{NO}_{3}^{-}-\mathrm{N}, \mathrm{NO}_{2}^{-}-\mathrm{N}, \mathrm{SO}_{4}^{2-}$ were measured by ion chromatograph (Dionex-4500i, Dionex Inc., Sunnyvale, CA, USA). TOC was measured by TOC Analyzer (Model Applo9000, Tekmar Dohrmann Inc., Mason, OH, USA). TCOD was determined with a standard microtechnique method [16]. The ORP was measured on line by 9778BN ORP electrode connected to an Orion-720A Analyzer (Orion Research Inc., Beverly, MA, USA). The $\mathrm{pH}$ was measured using a 9165BN pH electrode connected to Orion-828 pH Analyzer (Orion Research Inc., Beverly, MA, USA).

To measure the biomass in the effluent, phospholipids of the samples were extracted by chloroform-methanol. The treatment steps were detailed in the report of Islam and Suidan [12]. After pretreatment, the light absorbance of the samples was monitored using an ultraviolet raster spectrophotometer at $610 \mathrm{~nm}$ (Model 752, Shanghai Precision Science Instrument Inc.).

The fixed biomass of Sulfur Part was evaluated by determination of its COD [17], suspended solid (SS) and volatile suspended solid (VSS) [18]. The biofilm sample was taken out from Sulfur Part and the fixed biomass 
was recovered from the packed granules following the steps reported by Liu [17]. Then, the disrupted fixed biomass was diluted to $100 \mathrm{~mL}$ by distilled water and the COD, SS and VSS were analyzed by the standard methods [16].

Sample preparation for scanning electron microscope (SEM) was carried out as follows. The granules were put into $50-\mathrm{mL}$ serum bottle containing $4 \%$ glutaraldehyde in $0.05 \mathrm{~mol} / \mathrm{L}$ cacodylate buffer, then the bottle was sealed. Fixation was carried out for $12 \mathrm{~h}$ at $4^{\circ} \mathrm{C}$. The fixed granules were washed with phosphoric acid buffer (1:1) for three times, and then fixed with $1 \%$ osmium tetroxide. The granules were then dehydrated with a graded series of ethanol in distilled water from $50 \%$ to $100 \%(\mathrm{v} / \mathrm{v})$ and replaced by tert.-amyl acetate. The specimens were dried in $\mathrm{CO}_{2}$ critical point dryer (SPI Inc., PA, USA), mounted on brass discs, and sputter coated in Eiko Ion Coater (model IB-3, Hatachi Inc., Naka, Japan) with platinum/palladium target (60:40). The prepared specimens were examined (HITACHI S570 SEM, Hatachi Inc., Naka, Japan) at an accelerating voltage of $12 \mathrm{kV}$.

Sulfur denitrificans were identified by the classical cultivation and isolation methods [19].

\section{Results and discussion}

\subsection{Principle of the CBSAD system}

During the CBSAD process, nitrate is reduced to nitrogen gas by the biofilm on sulfur granule surface in Sulfur Part [20], and at the same time $\mathrm{H}^{+}$is produced:

$$
\begin{aligned}
& 55 \mathrm{~S}+50 \mathrm{NO}_{3}^{-}+38 \mathrm{H}_{2} \mathrm{O}+20 \mathrm{CO}_{2}+4 \mathrm{NH}_{4}^{+} \\
& \rightarrow 4 \mathrm{C}_{5} \mathrm{H}_{7} \mathrm{O}_{2} \mathrm{~N}+25 \mathrm{~N}_{2}+55 \mathrm{SO}_{4}^{2-}+64 \mathrm{H}^{+} .
\end{aligned}
$$

$\mathrm{H}^{+}$migrates to the upper Bioelectrochemical Part, and then it will be reduced into hydrogen gas through reaction (2) at the cathode:

$2 \mathrm{H}^{+}+2 \mathrm{e} \rightarrow \mathrm{H}_{2} \quad\left(e^{0}=0.000 \mathrm{~V}\right)$.

Another hydrogen gas production reaction occurred at the cathode is

$$
2 \mathrm{H}_{2} \mathrm{O}+2 \mathrm{e} \rightarrow \mathrm{H}_{2}+2 \mathrm{OH}^{-} \quad\left(e^{0}=-0.828 \mathrm{~V}\right)
$$

The electrode potentials for reactions (2) and (3) are about the same at $\mathrm{pH}=7$ according to the Nernst-Peters equation [21]. Therefore, from the point of view of energy consumption, both reactions (2) and (3) can take place simultaneously at the cathode. The hydrogen gas produced serves as the electron donor for further hydrogen denitrification by biofilm on the cathode [12], and the $\mathrm{H}^{+}$produced in Sulfur Part was also consumed:

$2 \mathrm{NO}_{3}^{-}+5 \mathrm{H}_{2}+2 \mathrm{H}^{+} \rightarrow \mathrm{N}_{2}+6 \mathrm{H}_{2} \mathrm{O}$.
In Bioelectrochemical Part, $\mathrm{CO}_{2}$ is formed prior to $\mathrm{O}_{2}$ at the anode according to their electrode potential as given in reactions (5) and (6) [22]:

$\mathrm{C}+2 \mathrm{H}_{2} \mathrm{O} \rightarrow \mathrm{CO}_{2}+4 \mathrm{H}^{+}+4 \mathrm{e} \quad\left(e^{0}=0.207 \mathrm{~V}\right)$,

$\mathrm{H}_{2} \mathrm{O} \rightarrow 1 / 2 \mathrm{O}_{2}+2 \mathrm{H}^{+}+2 \mathrm{e} \quad\left(e^{0}=1.229 \mathrm{~V}\right)$.

As a result, $\mathrm{CO}_{2}$ is produced and anoxic condition is provided in Bioelectrochemical Part, and the produced IC is supplied to the denitrification as IC source supplement. The produced $\mathrm{CO}_{2}$ is also dissolved and then dissociates into bicarbonate and carbonate ions to adjust $\mathrm{pH}$. Thus, favorable circumstance for the denitrification process in the whole reactor could be afforded.

The overall electrochemical reaction in Bioelectrochemical Part can be obtained from the combination of reactions (2), (3) and (5):

$\mathrm{C}+2 \mathrm{H}_{2} \mathrm{O} \rightarrow \mathrm{CO}_{2}+2 \mathrm{H}_{2}$.

Therefore, it can be considered that the $\mathrm{H}^{+}$produced by reaction (1) is not consumed by reactions (7) and (2) but by reaction (4).

\subsection{Influence of current on $\mathrm{ORP}, \mathrm{TOC}, \mathrm{TCOD}, \mathrm{NO}_{3}^{-}$, $\mathrm{NO}_{2}^{-}$and $\mathrm{pH}$ before inoculation}

The reactor was operated under 2-20 mA current for 2 weeks to test its electrochemical changes under continuous feeding. The HRT was $0.5-14 \mathrm{~h}$ and the influent nitrate concentration was $30 \mathrm{mg}-\mathrm{N} / \mathrm{L}$. The ORP decreased sharply from +200 to $-200 \mathrm{mV}$ after the current applied for $90 \mathrm{~min}$, and a favorable condition for denitrification could be easily formed in this system. The results were consistent with the research presented by Sakakibara et al. [23].

The concentration of TOC, TCOD, $\mathrm{NO}_{3}^{-}$and $\mathrm{NO}_{2}^{-}$in the reactor did not change during operation, which indicated that no organic pollutants were produced in the electrochemical reaction, and the current had no influence on the nitrate and nitrite variation without bacteria. Because $\mathrm{CO}_{2}$ was formed at the anode as reaction (7), the $\mathrm{pH}$ was keeping neutral under 2-20 $\mathrm{mA}$ currents. This $\mathrm{pH}$ condition was favorable to the denitrificans whose optimum $\mathrm{pH}$ was $6.5-8.0$ [24]. It can be concluded from the results mentioned above that the system was suitable for denitrification process.

\section{3. $\mathrm{pH}$ variation and $\mathrm{H}^{+}$balance in the denitrification process}

It can be concluded from Section 3.1 that neutral condition in the whole reaction could be provided when the $\mathrm{H}^{+}$produced from reaction (1) is balanced by reaction (4). Assuming that the bacteria yield coefficient 
is 0.08 , reaction (4) can be expressed as follows:

$$
\begin{aligned}
& 2 \mathrm{NO}_{3}^{-}+5 \mathrm{H}_{2}+5.04 \mathrm{H}^{+}+0.16 \mathrm{NH}_{4}^{+}+0.8 \mathrm{CO}_{2} \\
& \rightarrow 0.16 \mathrm{C}_{5} \mathrm{H}_{7} \mathrm{O}_{2} \mathrm{~N}+\mathrm{N}_{2}+7.28 \mathrm{H}_{2} \mathrm{O}
\end{aligned}
$$

It can be seen from reaction (8) that $2.52 \mathrm{~mol} \mathrm{H}^{+}$ would be consumed by hydrogen denitrification when $1 \mathrm{~mol} \mathrm{NO}_{3}^{-}-\mathrm{N}$ was reduced into nitrogen gas. The $\mathrm{H}^{+}$ consumed in reaction (8) should be afforded by sulfur denitrification, in which $1.97 \mathrm{~mol} \mathrm{NO}_{3}^{-}-\mathrm{N}$ was reduced to nitrogen gas according to reaction (1). Therefore, when the nitrate removal ratio of Bioelectrochemical part to Sulfur Part is 1:1.97, the $\mathrm{H}^{+}$will be balanced by sulfur and hydrogen denitrification and the whole reactor kept neutral. Furthermore, the $\mathrm{CO}_{2}$ produced on anode could also serve as $\mathrm{pH}$ buffer for the whole reactor.

Henze et al. reported that the optimum $\mathrm{pH}$ range is 79 [25] and Wang [24] reported it is 6.5-8.0 for denitrification. The influence of current on effluent $\mathrm{pH}$ of both Bioelectrochemical Part and Sulfur Part at $2.5 \mathrm{~h}$ HRT was shown in Fig. 2. It was shown in Fig. 2 that the effluent $\mathrm{pH}$ of both parts increased slightly with the increase of current, and the effluent was kept neutral when the current was near $12 \mathrm{~mA}$. If the current was lower than $12 \mathrm{~mA}$, some of the $\mathrm{H}^{+}$produced in sulfur denitrification (reaction (1)) could not be consumed by hydrogen denitrification (reaction (8)), which resulted in lower effluent $\mathrm{pH}$. When the current was less than $12 \mathrm{~mA}$, more $\mathrm{H}_{2}$ would be supplied from reaction (7) for reaction (8) with the increase of applied current, and more $\mathrm{H}^{+}$produced by reaction (1) will be consumed accordingly. Therefore, the effluent $\mathrm{pH}$ increases with the increase of current when the applied current is less than $12 \mathrm{~mA}$. When the applied current increased to $12 \mathrm{~mA}$, the nitrate removal ratio of Bioelectrochemical Part (124.3 mg-N) to Sulfur Part $(244.7 \mathrm{mg}-\mathrm{N})$ was $1: 1.97$, thus the $\mathrm{H}^{+}$produced $(23.4 \mathrm{mmol})$ from reaction (1) was totally consumed by reaction (8) (23.4 $\mathrm{mmol} \mathrm{H}^{+}$consumed) and neutral effluent from both parts could be obtained. At $12 \mathrm{~mA}$ current, the $\mathrm{pH}$ of Sulfur Part effluent was almost the same as that of SLAD system [26]. If the current was higher than $12 \mathrm{~mA}$, the $\mathrm{H}^{+}$needed by reaction (8) was more than that produced from reaction (1), however, the produced $\mathrm{CO}_{2}$ could buffer $\mathrm{pH}$ to keep neutral as seen in Fig. 2. The neutral effluent of CBSAD reactor showed that the CBSAD reactor could adjust $\mathrm{pH}$ effectively without limestone, and the effluent hardness increase could be avoided. Because the $\mathrm{pH}$ adjustment in Sulfur Part was provided by reaction (8) in Bioelectrochemical Part and certain time was needed for $\mathrm{H}^{+}$transportation to the cathode, the effluent $\mathrm{pH}$ of Sulfur Part was about 0.2 lower than that of Bioelectrochemical Part under the same current.

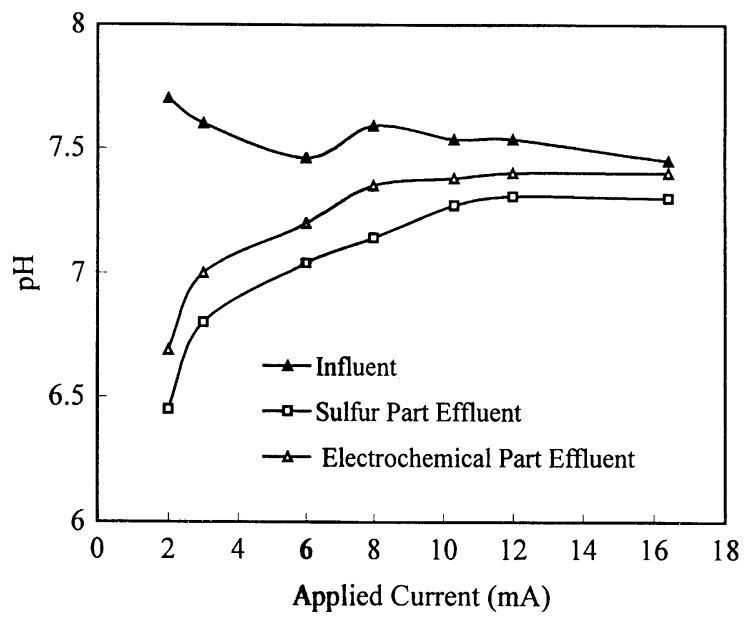

Fig. 2. $\mathrm{pH}$ of influent and effluent.

\subsection{Influence of current on denitrification and current efficiency}

In this CBSAD reactor, nitrate was firstly reduced in Sulfur Part, and then the residual nitrate was further reduced in Bioelectrochemical Part. Under the condition of $2.5 \mathrm{~h} \mathrm{HRT}$ and $30 \mathrm{mgNO}_{3}^{-}-\mathrm{N} / \mathrm{L}$ influent, the effect of current on both denitification efficiency and electric current efficiency was illustrated in Fig. 3. Voltage of 1.8-4.0 V was applied to the CBSAD reactor and the corresponding current were 2-20 mA. As shown in Fig. 3, the nitrate removal in Sulfur Part increased slightly with the applied current from $70 \%$ to $78.9 \%$ because of slight $\mathrm{pH}$ increase, and about $2.6 \mathrm{mg}-\mathrm{N} / \mathrm{L}$ nitrite was accumulated at $2.5 \mathrm{~h}$ HRT. The residual nitrate and accumulated nitrite would flow into the upper Bioelectrochemical Part for further removal. It can be seen from Fig. 3 that the current intensity had great influence on the denitrification in Bioelectrochemical Part, which is in accordance with the research of Isam and Suidan [12]. Both the nitrate and nitrite removal were increased steadily with the increase of current. About $87 \%$ nitrate could be removed when the current went up to $10 \mathrm{~mA}$, and the residual nitrate and nitrite in the effluent were about 5.0 and $0.09 \mathrm{mg}-\mathrm{N} / \mathrm{L}$, respectively. And the higher the current, the better the removal rate. Under $12 \mathrm{~mA}$ current, no nitrite was detected in the effluent and the nitrate removal was increased to $90 \%$. Nitrate removal was up to $100 \%$ when $18 \mathrm{~mA}$ current was applied. These results suggested that the applied current be the key influencing factor on the CBSAD process under the voltage from 1.8 to $4.0 \mathrm{~V}$.

During hydrogen denitrification, both reaction (4) and (9) were taken place in biofilm on cathode:

$2 \mathrm{NO}_{2}^{-}+4 \mathrm{H}_{2} \rightarrow \mathrm{N}_{2}+4 \mathrm{H}_{2} \mathrm{O}$ 


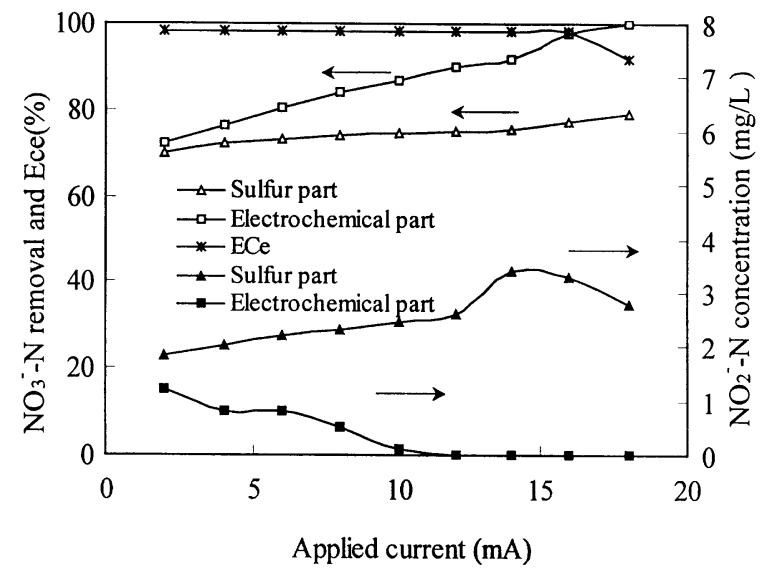

Fig. 3. Nitrate removal and electric current efficiency at $2.5 \mathrm{~h}$ HRT.

i.e. $5 \mathrm{~mol}$ electron in reaction (4) and $3 \mathrm{~mol}$ electron in reaction (9) are consumed in the reduction of $1 \mathrm{~mol}$ of nitrate and nitrite, respectively. The effective current $\left(I_{\mathrm{E}}\right)$ of Bioelectrochemical Part, which is determined by the nitrate loading, was defined as

$$
\begin{aligned}
I_{\mathrm{E}}= & {\left[\left(C_{\text {in }}-C_{\text {eff }}\right) 5+\left(C_{2 \text { in }}-C_{2 \mathrm{eff}}\right) 3\right] } \\
& \times V F / H R T,
\end{aligned}
$$

where $C_{\text {in }}$ and $C_{\text {eff }}$ is influent and effluent nitrate concentration of Bioelectrochemical Part (mol-N/L), $C_{2 \text { in }}$ and $C_{\text {2eff }}$ are influent and effluent nitrite concentration of Bioelectrochemical Part (mol-N/L), $F$ is Faraday constant $(\mathrm{C} / \mathrm{mol}), V$ is the effective volume (L). So the electric current efficiency $\left(\mathrm{EC}_{\mathrm{e}}\right)$ was defined as the ratio of $I_{\mathrm{E}}$ to the applied current $(I)$, i.e., $\mathrm{EC}_{\mathrm{e}}=I_{\mathrm{E}} / I$. It can be concluded from Fig. 3 that the $\mathrm{EC}_{\mathrm{e}}$ of Bioelectrochemical Part kept $98 \%$ until the current was increased to $16 \mathrm{~mA}$. Then the efficiency decreased with the increase of applied current, and it would be decreased to $92 \%$ at $18 \mathrm{~mA}$, which was resulted from the incomplete consumption of hydrogen gas by hydrogen denitrification. During denitrification process, the total IC was sufficient for the growth of autotrophic denitrifying microorganisms, which can be calculated by reactions (1) and (8) stoichiometrically.

\subsection{The minimum current at different $H R T$}

To determine the optimum operation conditions, the experiment was carried out at different current and HRT, and the influent nitrate concentration was kept at $30 \mathrm{mg}-\mathrm{N} / \mathrm{L}$. The minimum current was defined as that which yield $90 \%$ nitrate removal, i.e. the effluent nitrate and sulfate concentration was lower than $3.0 \mathrm{mg}-\mathrm{N} / \mathrm{L}$ and $170 \mathrm{mg} / \mathrm{L}$ while no nitrite was detected. The minimum current of different HRT were shown in

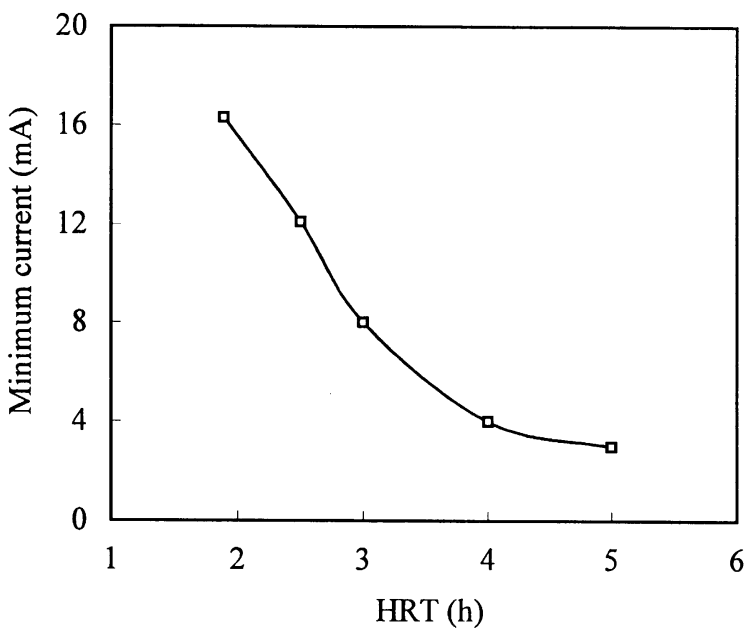

Fig. 4. Minimum current at different HRT.

Fig. 4. It can be seen from Fig. 4 that the minimum current must be increased with the decrease of HRT to maintain $90 \%$ denitrification efficiency. For example, the minimum current of the reactor must be increased to $16 \mathrm{~mA}$ to obtain $90 \%$ denitrification removal under $1.9 \mathrm{~h}$ HRT. The nitrate and nitrite concentration in Sulfur Part effluent decreased with the increase of HRT, so $90 \%$ nitrate removal could be attained at lower current intensity in Bioelectrochemical Part. If the HRT increased to $5 \mathrm{~h}, 3 \mathrm{~mA}$ current was enough to obtain $90 \%$ denitrification efficiency. When the HRT was higher than $5 \mathrm{~h}, 90 \%$ denitrification efficiency without nitrite accumulation was produced in Sulfur Part at $3 \mathrm{~mA}$ current, and the sulfate concentration was higher than $170 \mathrm{mg} / \mathrm{L}$. Therefore, Bioelectrochemical Part played no role in the nitrate removal under such conditions, and the operation HRT of the combined reactor should not be higher than $5 \mathrm{~h}$. When the current was lower than $3 \mathrm{~mA}$, pH in Sulfur Part was lower than 6.5 (Fig. 2), and nitrate removal could not reach $90 \%$ at any HRT. So $3 \mathrm{~mA}$ was the minimum current for CBSAD reactor to work effectively. During the operation, the maximum volume-loading rate (VLR) was $0.381 \mathrm{~kg} \mathrm{NO}-\mathrm{N} /\left(\mathrm{m}^{3} \mathrm{~d}\right)$, and the maximum electrode surface loading rate (ESLR) of the cathode was $0.043 \mathrm{mg} \mathrm{NO}_{3}^{-}-\mathrm{N} /\left(\mathrm{cm}^{2} \mathrm{~d}\right)$.

\section{6. $\mathrm{SO}_{4}^{2-}$ in the effluent}

When the nitrate concentration of the influent was $30 \mathrm{mg}-\mathrm{N} / \mathrm{L}$, the variation of $\mathrm{SO}_{4}^{2-}$ in the effluent was given in Fig. 5. The effluent sulfate concentration could be controlled by HRT and current adjustment. It can be concluded from Fig. 5 that effluent sulfate concentration remained lower than $170 \mathrm{mg} / \mathrm{L}$ during the whole operation period $(400 \mathrm{~d})$, which met the secondary 


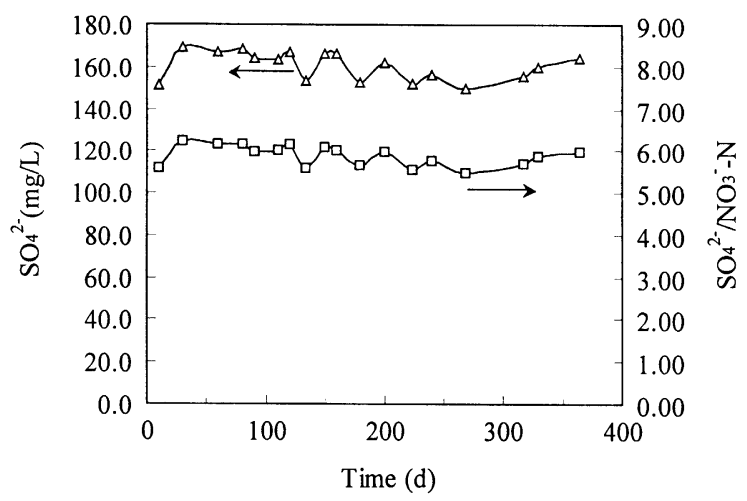

Fig. 5. Sulfate and $\mathrm{SO}_{4}^{2-} / \mathrm{NO}_{3}^{-}-\mathrm{N}$ ratio change in effluent.

maximum contaminant level of sulfate from the US EPA, i.e. $250 \mathrm{mg} / \mathrm{L}$. The effluent sulfate of this CBSAD reactor was also lower than that of conventional sulfur denitrification reactor and SLAD system under the same influent concentration $[10,26]$. The concentration ratio of sulfate to consumed $\mathrm{NO}_{3}^{-}-\mathrm{N}$ was between 5.20 and 5.80 , which was lower than the reported values of 6.4 , $7.89,9.9,11.1[27-29,15]$ and the stoichiometric value of 7.45. The residual nitrate removal in Bioelectrochemical Part led to lower nitrate loading of Sulfur Part, thus decreased sulfate concentration in the effluent.

\subsection{Biomass analysis}

The biomass in the two parts effluent was very low and did not change obviously with operation time. The phospholipid concentration was about $0.88 \times 10^{-6} \mathrm{~mol} /$ $\mathrm{L}$ in Sulfur Part effluent and $0.64 \times 10^{-6} \mathrm{~mol} / \mathrm{L}$ in Bioelectrochemical Part effluent. TCOD in the effluent of both parts was lower than $10 \mathrm{mg} / \mathrm{L}$.

The variation of the COD, SS and VSS of the fixed biomass in Sulfur Part was illustrated in Fig. 6. Under the condition of $12 \mathrm{~mA}$ current and $2.5 \mathrm{~h} \mathrm{HRT}$, the biomass decreased with the increase of the reactor height. At the height of $1.1 \mathrm{~cm}$, the COD, SS, and VSS were $319,17.8$ and $17.1 \mathrm{mg} / \mathrm{g}$-packed-granule, and they were decreased to $164,4.6$ and $3.1 \mathrm{mg} / \mathrm{g}$-packed-granule at the top of Sulfur Part (35 cm height). The abovementioned phenomena were resulted from nitrate decrease with the increase of the reactor height. As the electron donor, the nitrate decrease led to the decrease of denitrificans and the biomass.

Under $1.9 \mathrm{~h}$ HRT and quasi-steady-state condition, the COD, SS, and VSS were $150,3.9$ and $2.8 \mathrm{mg} / \mathrm{g}$ packed-granule at the top of Sulfur Part under $12 \mathrm{~mA}$ current, and they were increased to $200,6.1$ and $4.2 \mathrm{mg} /$ g-packed-granule at $6 \mathrm{~mA}$ current. Similar phenomena were observed at other HRTs, which showed that the applied current in Bioelectrochemical Part also influenced the biomass amount at the top of Sulfur Part.

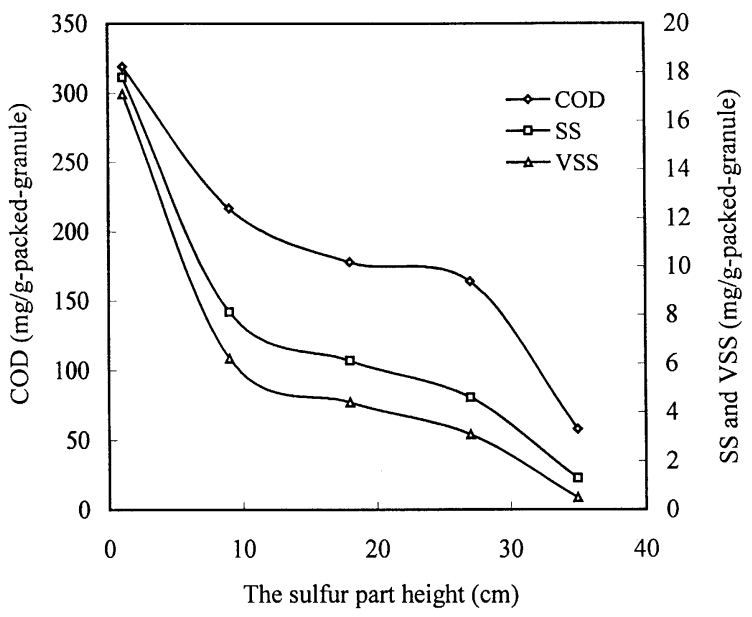

Fig. 6. Biomass distribution of Sulfur Part.

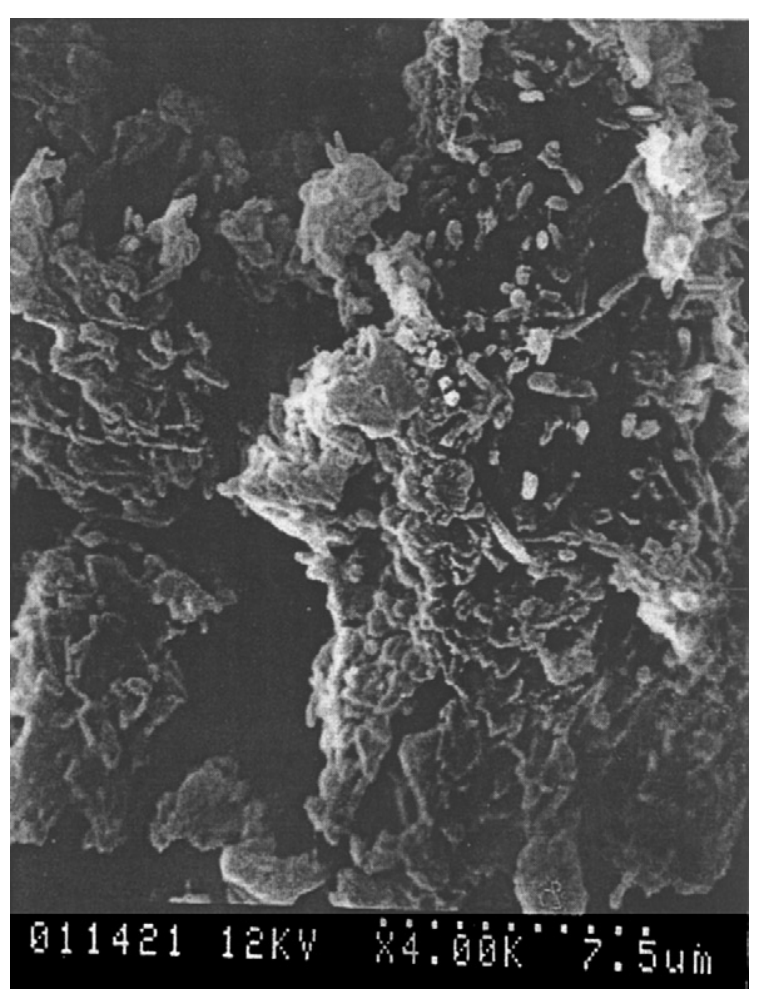

Fig. 7. SEM micrographs of the granule surface at the height of $18 \mathrm{~cm}$.

However, the biomass amount at the top of Sulfur Part could be neglected comparing with the whole biomass amount of Sulfur Part at certain conditions. The nitrate removal of the biomass at the top of Sulfur Part could be neglected comparing with the whole nitrate removal of Sulfur Part accordingly, i.e. the whole nitrate removal of Sulfur Part was not influenced by the biomass change at the top of Sulfur Part under certain HRT. Therefore, 
the current influence on the biomass at the top of Sulfur Part was not conflict with the results in Section 3.4, i.e. the whole nitrate removal of Sulfur Part increased slightly with the increase of the applied current (Fig. 3) because of slight $\mathrm{pH}$ increase.

The SEM micrographs of the granule surface at the height of $18 \mathrm{~cm}$ in Sulfur Part under $12 \mathrm{~mA}$ current and 2.5 h HRT was illustrated in Fig. 7. The structure and diversity of the microorganisms on the granule surface were presented in the micrographs, from which it can be concluded that the packed granule surface have complex bacterial composition with some lacuna. Thiobacillus denitrificans were identified as the predominant denitrificans on the granule surface. It could be deduced from the result that Thiobacillus denitrificans clustered with other denitrificans, inorganic material and extracellular polymers to carry out the sulfur denitrification process.

\section{Conclusions}

It is clear from the results in this paper that combining the bioelectrochemical autotrophic denitrification and sulfur autotrophic denitrification into one process is possible for drinking water treatment. The two denitrification processes could realize in this integrated process, and high denitrification efficiency could be obtained. The $\mathrm{H}^{+}$produced in Sulfur Part could be consumed in Bioelectrochemical Part, which was helpful to the hydrogen denitrification and effluent neutralization of both parts. The limestone for $\mathrm{pH}$ adjustment in Sulfur Part was not necessary and therefore the hardness increase in the effluent could be avoided. This CBSAD reactor could provide a favorable $\mathrm{pH}$ environment for denitrification under optimum operation conditions.

Because bioelectrochemical hydrogen denitrification and sulfur denitrification proceeded in one reactor, only part of the nitrate removal carried out in Sulfur Part through HRT and current adjustment. Therefore, the sulfate concentration in the final effluent of the CBSAD reactor was lower than $170 \mathrm{mg} / \mathrm{L}$, which was lower than that of the SLAD and conventional sulfur denitrification system.

The optimum HRT was $1.9-5 \mathrm{~h}$ and the corresponding minimum current was $3-16 \mathrm{~mA}$. Under the optimum conditions mentioned above, the nitrate removal was higher than $90 \%$ and even up to $100 \%$ without nitrite accumulation. The maximum VLR of the reactor was $0.381 \mathrm{~kg} \mathrm{NO}-\mathrm{N} /\left(\mathrm{m}^{3} \mathrm{~d}\right)$, and the maximum ESLR of cathode was $0.043 \mathrm{mg} \mathrm{NO}--\mathrm{N} /\left(\mathrm{cm}^{2} \mathrm{~d}\right)$.

Attached biomass in Sulfur Part decreased with the height increase of the reactor, and the predominant denitrifying bacteria in Sulfur Part were Thiobacillus denitrificans. The current in Bioelectro- chemical Part also influenced the amount of denitrificans at the top of Sulfur Part, and further studies should be carried out to investigate the mechanism of this phenomenon.

\section{Acknowledgements}

This study was supported by the Natural Science Fund for Distinguished Young Scholars (No. 50225824), National Key Basic Research Science foundation (No. 1999045710), Natural Sciences foundation of China (No. 50078052) and the Special Funds for the Scientific and Social Practice of CAS (for Innovative Research).

\section{References}

[1] Follett RF, edtor. Nitrogen management and ground water protection. New York: Elsevier; 1989. p. $1-5$.

[2] Fan B, Qu JH. Nitrate removal from drinking water by three-dimension electrode electrochemical-biofilm reactors. J Acta Scientiae Circumstantiae 2001;21(1):39-43 [In Chinese].

[3] Sakakibara Y, Araki K, Watanabe T, Kuroda M. The denitrification and neutralization performance of an electrochemically activated biofilm reactor used to treat nitrate-conaminated groundwater. Water Sci Technol 1997;36(1):61-8.

[4] Winto EF. Nitrate in drinking water. J Am Water Works Assoc 1997;63:95-104.

[5] Removal of inorganic contaminants. In: Gillies MT, editor. Drinking water detoxification. New Jersey: Noyes Data Corporation; 1978. p. 291.

[6] Shuval HI. Infant methemoglobinemia and other health effects of nitrates in drinking water. Prog Water Technol 1980;12:1731-6.

[7] Mirvish SS. N-nitroso compounds, nitrate, and nitrite: possible implications for the causation of human cancer. Prog Water Technol 1977;8:195-204.

[8] Flere JM, Zhang TC. Sulfur-based autotrophic denitrification pond systems for in situ remediation of nitratecontaminated surface water. Water Sci Technol 1998;38(1): $15-22$.

[9] Zhang TC, David GL. Sulfur:limestone autotrophic denitrification processes for treatment of nitrate-contaminated water: batch experiments. Water Res 1999;33(3): 599-608.

[10] Kurt M, Dunn IJ, Bource JR. Biological denitrification of drinking water using autotrophic organisms with $\mathrm{H}_{2}$ in a fluidized-bed biofilm reactor. Biotechnol Bioeng 1987;29: 493-501.

[11] Batchelor B, Lawrence AW. Autotrophic denitrification using elemental sulfur. J Water Pollut Control Fed 1978; 50:1986-2001. 
[12] Islam S, Suidan MT. Electrolytic denitrification: long-term performance and effect of current intensity. Water Res 1998;32(2):528-36.

[13] Sakakibara Y, Flora JRV, Suidan MT, Kuroda M. Modelling of electrochemically actived denitrification. Water Res 1994;28(5):1077-86.

[14] van der Hoek, JP, Hijnen WAM, van Bennekom CA, Mijnarends BJ. Optimization of the sulphur-limestone filtration process for nitrate removal from groundwater. J Water SRT-Aqua 1992;41:209-18.

[15] Schippers JC, Kruithof JC, Mulder FG, van Lieshout JW. Removal of nitrate by slow sulphurlimestone filtration. J Aqua 1987;5:274-80.

[16] APHA, AWWA, WEF. Standard methods for the examination of water and wastewater, 18th ed. Washington, DC: APHA, AWWA, WEF; 1992. p. 5, 390.

[17] Liu Y. Estimating minimum fixed biomass concentration and active thickness of nitrifying biofilm. J Environ Eng 1997;123(2):198-202.

[18] Wirtz RA, Dague RR. Enhancement of granulation and start-up in the anaerobic sequencing batch reactor. Water Environ Res 1996;68(5):883-92.

[19] Buchanan RE, Gibbons NE, editors. Bergey's manual of determinative bacteriology, 8th ed. Baltimore, MD: Williams \& Wilkins; 1974.

[20] Batchelor B, Lawrence AW. A kinetic model for autotrophic denitrification using elemental sulfur. Water Res 1978;12:1075-84.
[21] Oxidation and reduction titration methods. In: Wuhan University, editor. Analytical chemistry, 3rd ed. Beijing: Higher Education Press; 1995. p. 355.

[22] Kinoshita K. Carbon, electrochemical and physicochemical properties. New York: Wiley; 1988.

[23] Sakakibara Y, Araki K, Tanaka T, Watanabe T, Kuroda M. Denitrification and neutralization with an bioelectrochemical and biological reactor. Water Sci Technol 1994;30(6):151-5.

[24] Wang YR. Theory, experiment of enhancing biological denitrificatioin efficiency for the wastewater. J Environ Prot Petrochem Ind 1995;93:1-5 [In Chinese].

[25] Henze M, Harrëmoes P, Jansen JL, Arvin E. Wastewater treatment biological and chemical processes. Lyngby, Denmark: Polyteknisk Forlag; 1992. p. 78 [in Danish].

[26] Flere JM, Zhang TC. Nitrate removal with sulfur-limestone autotrophic denitrification processes. J Environ Eng 1999; 125(8):721-9.

[27] Sikora LJ, Keeney DR. Evaluation of a sulfur-Thiobacillus denitrificans nitrate removal system. J Environ Qual 1976;5(3):298-303.

[28] Koenig A, Liu LH. Autotrophic denitrification of landfill leachate using elemental sulphur. Water Sci Technol 1996;34(5-6):469-76.

[29] Hashimoto S, Furukawa K, Shioyama M. Autotrophic denitrification using elemental sulfur. J Ferment Technol 1987;63(5):683-92. 